\title{
ANALISIS PERTUMBUHAN EKONOMI KABUPATEN/KOTA HASIL PEMEKARAN DI INDONESIA
}

\author{
Analysis of Economic Growth of Redistricting Regency/City in Indonesia
}

\author{
Rasyid Widada1, Dedi Budiman Hakim², Sri Mulatsih²
}

1Staff Tenaga Ahli pada PT. Bina Insan Negeri. Jakarta. E-mail: rasyid_w@yahoo.com

2 Staff Pengajar Departemen Ilmu Ekonomi. Fakultas Ekonomi dan Manajemen Institut Pertanian Bogor. E-mail: dedihakim@gmail.com, mulatsupardi@gmail.com

\begin{abstract}
This research aims to analyze the effects of government expenditure and labor on economic growth of the new districts of regional reform during the period 2008-2010. Government expenditure variable using numbers the realization of total government spending. The variable of labor using figures of employment. The variables of economic growth using the number of GRDP without oil and gas at 2000 constant market prices. The samples involved are 45 new districts by regional reform selected at random from 26 province. Data used are secondary data, while the data analysis used is regression panel data. The result showed that government expenditure, infrastructure, and labor influence positively and very significant on economic growth of the new districts by regional reform. Every $1 \%$ increase in total government expenditure will increase $0.223534 \%$ of GRDP. Every $1 \%$ increase in the number of employment will increase $0.298281 \%$ of GRDP.
\end{abstract}

Key Word : regional expansion, economic growth, government expenditure, infrastructure, labor

\begin{abstract}
ABSTRAK
Penelitian ini bertujuan untuk menganalisis pengaruh variabel belanja pemerintah, infrastruktur, dan tenaga kerja terhadap pertumbuhan ekonomi kabupaten/kota hasil pemekaran daerah selama periode 2008-2010. Variabel belanja pemerintah menggunakan angka realisasi total belanja pemerintah. Variabel infrastruktur menggunakan rasio panjang jalan yang menjadi kewenangan pemerintah kabupaten/kota hasil pemekaran terhadap luas wilayah darat mereka. Variabel tenaga kerja menggunakan angka kesempatan kerja. Sedangkan variabel pertumbuhan ekonomi menggunakan angka PDRB Non minyak dan gas atas dasar harga konstan tahun 2000. Sampel yang dilibatkan adalah 45 kabupaten/kota hasil pemekaran daerah yang dipilih secara acak dari 26 provinsi. Data yang dipakai adalah data sekunder, sedangkan analisis data yang digunakan adalah regresi data panel. Hasil penelitian menunjukkan bahwa secara bersama-sama variabel belanja pemerintah, infrastruktur, dan tenaga kerja berpengaruh positif dan signifikan terhadap pertumbuhan ekonomi kabupaten/kota hasil pemekaran. Setiap kenaikan total belanja pemerintah kabupaten/kota hasil pemekaran sebesar $1 \%$ akan meningkatkan PDRB sebesar 0,110092\%. Setiap kenaikan rasio panjang jalan yang menjadi wewenang pemerintah kabupaten/kota hasil pemekaran terhadap luas wilayahnya sebanyak $1 \%$ akan meningkatkan PDRB sebesar 0,256128\%. Setiap kenaikan $1 \%$ angka kesempatan kerja di kabupaten/kota hasil pemekaran akan meningkatkan PDRB sebesar 0,295785\%.
\end{abstract}

Kata kunci: pemekaran daerah, pertumbuhan ekonomi, belanja pemerintah, infrastruktur, tenaga kerja.

\section{PENDAHULUAN}

Dalam konteks pembangunan ekonomi, pemekaran wilayah diharapkan akan mendorong pengembangan dan kreatifitas baru dalam mengelola potensi daerah yang dimiliki. Dorongan ini akan meningkatkan peluang untuk menggali berbagai potensi ekonomi daerah baru yang selama ini kurang terperhatikan. Di 
samping itu, dengan adanya daerah baru hasil pemekaran diharapkan akan merangsang terbentuknya pusat-pusat pertumbuhan ekonomi baru (new economic growth centers) yang akan mendorong percepatan pembangunan ekonomi daerah. Karena beberapa alasan itulah maka dalam UU No 32 Tahun 2004 tentang Pemerintahan Daerah mengakomodasi pengaturan masalah pemekaran daerah.

Sejak reformasi bergulir hingga terakhir dilakukannya pemekaran daerah baru pada Desember 2012, pemerintah telah melakukan 217 pemekaran daerah. Akibatnya, jumlah daerah di Tanah Air semakin banyak, yakni 34 provinsi dan 502 kabupaten/kota. Namun, dalam perkembangannya banyak sekali daerah hasil pemekaran yang dinilai berkinerja buruk. Evaluasi yang dilakukan Direktorat Jenderal Otonomi Daerah Kementerian Dalam Negeri (2011) terhadap 205 daerah hasil pemekaran yang terbentuk antara tahun 1999-2009 (terdiri atas 164 kabupaten, 34 kota, dan 7 provinsi) menyimpulkan bahwa masih sekitar 70 persen daerah pemekaran dinilai belum berhasil. Hasil evaluasi tersebut senada dengan evaluasi yang dilakukan Badan Perencanaan Pembangunan Nasional (Bappenas) bekerjasama dengan United Nations Development Programme (UNDP) pada 2008 yang menemukan bahwa secara umum daerah otonom baru masih tertinggal. Kondisi tersebut memunculkan sejumlah diskusi ataupun kajian untuk membahas upaya-upaya peningkatan kesejahteraan ekonomi di daerah-daerah baru hasil pemekaran daerah.

Terdapat berbagai sudut pandang yang sering digunakan untuk melihat kinerja daerah hasil pemekaran dalam meningkatkan pertumbuhan ekonomi. Tinjauan pertama yang sering digunakan adalah aspek pengeluaran atau belanja pemerintah (public expenditure). Rujukan yang sering dipakai adalah teori pengeluaran pemerintah yang

2 dikemukakan Rostow dan Musgrave. Teori ini mengaitkan pengeluaran pemerintah dalam tiga tahapan pembangunan ekonomi, yaitu: tahap awal, tahap menengah dan tahap lanjut. Pemerintah daerah hasil pemekaran dalam pemahaman teori tersebut dapat dikatakan berada pada tahap awal. Karakteristik pengeluaran pemerintah pada tahap awal adalah pengeluaran untuk investasi merupakan bagian yang terbesar dari total belanja. Pengeluaran investasi tersebut ditujukan untuk pengadaan sarana maupun prasarana publik, seperti: infrastruktur transportasi, pendidikan, kesehatan, pemerintahan, dan lain sebagainya (Mangkoesoebroto, 1997).

Tinjauan kedua yang juga banyak diketengahkan terkait dengan peningkatan pertumbuhan ekonomi di daerah hasil pemekaran adalah tenaga kerja. Menurut pandangan ekonom neoklasik, tenaga kerja dinilai sebagai faktor penting dalam menciptakan pertumbuhan ekonomi. Teori pertumbuhan ekonomi Solow menjelaskan bahwa pertumbuhan populasi mempengaruhi pertumbuhan ekonomi. Hal ini karena jumlah tenaga kerja sangat ditentukan oleh jumlah populasi (Mankiw, 2000). Meningkatnya jumlah tenaga kerja akan membuat kenaikan dalam jumlah barang yang diproduksi. Tetapi pada sisi yang lain, besarnya jumlah tenaga kerja akan menyebabkan terhambatnya pembangunan ekonomi jika pertambahan jumlah tenaga kerja tidak diimbangi dengan pertumbuhan kesempatan kerja. Dalam konteks pemekaran daerah, pemisahan dari daerah induk akan berdampak pada menurunnya jumlah populasi yang tentu saja akan berdampak pada menurunnya jumlah tenaga kerja. Namun jika pemerintah daerah pemekaran dapat mendayagunakan potensi daerahnya untuk meningkatkan kesempatan kerja, tentu hal ini akan menjadi pendorong positif pertumbuhan ekonomi daerah.

Berdasarkan pemaparan di atas maka kajian ini mencoba menganalisis pertumbuhan ekonomi di daerah baru hasil pemekaran berdasarkan ketiga tinjauan di atas, yakni: belanja pemerintah, infrastruktur, dan tenaga kerja. Dengan demikian permasalahan yang akan dibahas 
dalam penelitian ini adalah sebagai berikut:

a. Bagaimana perkembangan pertumbuhan ekonomi kabupaten/kota hasil pemekaran di Indonesia?

b. Bagaimana perkembangan belanja pemerintah dan tenaga kerja beserta pengaruhnya terhadap pertumbuhan ekonomi kabupaten/kota hasil pemekaran di Indonesia?

\section{TINJAUAN PUSTAKA}

\section{Pemekaran Daerah}

Pemekaran daerah menurut Gabrielle Ferrazi (2007) dapat dilihat sebagai bagian dari proses penataan daerah atau territorial reform atau administrative reform, yaitu "management the size, shape, and hierarchy of local government units for the purpose of achieving political and administrative goals". Penataan daerah umunya mencakup pemekaran, penggabungan, dan penghapusan daerah. Ferrazi berpendapat bahwa grand strategy otonomi daerah yang optimal tidak berhenti pada menentukan berapa jumlah daerah otonom yang ideal di suatu negara, namun lebih dari itu, harus mampu menjawab pertanyaan apa sebenarnya hakikat otonomi daerah di negara yang bersangkutan. Baru setelah itu mencari "jawaban" untuk tujuan apa sebenarnya pemekaran daerah (dalam konteks territorial reform) tersebut.

Alasan pemekaran daerah tidak pernah tunggal, bahkan seringkali tumpang tindih antara alasan yang bersifat sosial, politik, maupun ekonomi. Alasan pertama yang sering disampaikan dalam usulan pemekaran daerah adalah kondisi georgrafis yang terlalu luas yang berdampak pada kualitas layanan publik. Dalam kajian Bappenas dan UNDP (2008) disebutkan pula bahwa salah satu argumen yang mendukung pemekaran, yaitu antara lain karena adanya kebutuhan untuk mengatasi jauhnya jarak rentang kendali antara pemerintah dan masyarakat. Rentang kendali yang lebih pendek dan alokasi fiskal yang lebih merata seyogyanya menjadi modal dasar bagi peningkatan pelayanan di setiap daerah, khususnya daerah pemekaran. Tidak efektif dan efisiennya pelayanan kepada masyarakat akibat wilayah yang tidak dimekarkan misalnya terjadi pada kasus pelayanan administrasi perijinan yang mengharuskan warga yang jauh dari ibukota harus mengeluarkan biaya dan waktu lebih banyak untuk pengurusan SIM/STNK, pengurusan pajak, penyelesaian sidang pengadilan, dan lainlain sebagainya. Selain pelayanan administrasi, pemusatan layanan kesehatan, pendidikan, dan layanan sosial yang lain juga menyebabkan tidak efektif dan efisiennya pelayanan kepada masyarakat.

Alasan kedua yang sering dikemukakan adalah masyarakat di suatu daerah merasakan adanya ketimpangan pemerataan dan keadilan antara daerah yang satu dengan yang lain dalam satu wilayah pemerintahan daerah. Daerah yang dekat dengan pusat kekuasaan (ibukota) cenderung lebih mendapatkan perhatian daripada daerah yang jauh dari pusat kekuasaan. sehingga daerah tersebut merasakan adanya ketimpangan pemerataan dan keadilan dari pemangku kekuasaan. Apalagi ketika kelompok tersebut memiliki ciri-ciri sosial yang sama seperti etnisitas, agama, kesejarahan dan tingkat kohesivitas yang tinggi maka kecenderungan untuk menuntut pembentukan pemerintahan daerah sendiri cenderung amat tinggi. Kelompok warga tersebut beranggapan bahwa ketika mereka memiliki pemerintahan daerah sendiri maka mereka akan mengelola kepentingan mereka menjadi lebih efektif dan responsif sehingga kemakmuran warganya juga akan menjadi semakin baik. Pembentukan daerah baru dianggap dapat menjadi solusi terhadap ketidakadilan dalam hubungan antar kelompok tetapi juga dapat memperkuat indentitas kelompok dan daerah. Alasan ketimpangan dan ketidakadilan ini misalnya mencuat dalam pembentukan Provinsi Kepulauan Riau, 
Bangka Belitung, dan Sulawesi Barat (Pusat Kajian Kinerja Otonomi Daerah LAN, 2005).

Alasan ketiga yang turut melatarbelakangi keinginan untuk pemekaran daerah adalah adanya perbedaan sosio-kultural atau etnis. Sebagai misal: masyarakat Bangka Belitung merasa berbeda dengan masyarakat Sumatera Selatan, kemudian masyarakat Gorontalo merasa berbeda dengan masyarakat Sulawesi Utara. Demikian pula penduduk Kabupaten Minahasa Utara yang merasa berbeda budaya dengan penduduk Kabupaten Minahasa dan Kabupaten Minahasa Selatan. Dalam bentuk lain, ada juga masyarakat yang mengajukan pemekaran merasa sebagai komunitas budaya tersendiri yang berbeda dengan komunitas budaya daerah induk. Sebagai contoh: masyarakat Banten merasa secara budaya berbeda dengan masyarakat Jawa Barat. Demikian pula dengan yang terjadi dalam banyak pemekaran kabupaten di Provinsi Papua.

Alasan keempat adalah alasan politik. Alasan ini memang tidak pernah pernah secara eksplisit disampaikan sebagai alasan pemekaran suatu daerah. Namun nuansa motif politik dalam pengusulan pemekaran suatu daerah akan terasa jika melihat elit dan kekuatan politik yang terlihat begitu besar perannya dalam proses pengusulan pemekaran daerah. Sudah menjadi rahasia umum jika alasan dilakukannya pemekaran adalah keinginan sekelompok elit politik untuk memperoleh posisi kekuasaan baru di daerah yang dimekarkan. Hal ini karena keberadaan daerah otonomi baru hasil pemekaran daerah membuka peluang dibentuk aparat pemerintah daerah baru. Di samping itu, adanya daerah pemekaran baru juga membuka peluang partai-partai politik menambah "alokasi" penempatan elitelitnya untuk menduduki jabatan politik. Daerah pemekaran baru juga berpeluang mengkonsentrasikan dan mengkonsolidasikan basis dukungan atau konstituen tradisional yang dimiliki sebuah kekuatan politik di suatu daerah. Dikemukakan oleh Tri Ratnawati dan Robert E. Jaweng (2005) bahwa ada kecurigaan dari sebagian kalangan bahwa merebaknya jumlah pemekaran kabupaten/kota baru di Indonesia pada dekade 2000-an merupakan strategi divide and rule (memecah belah dan menguasai) dari pemerintahan pusat yang bertujuan mempermudah pengendalian daerahdaerah dan elit-elit yang telah terpecah. Motif lainnya adalah untuk pemenangan pemilu dengan cara melakukan pembelahan daerah pemilihan secara politik (gerrymander). Ini terjadi pada kasus pemekaran Papua di masa pemerintahan Presiden Megawati Soekarnoputri (yang berasal dari PDIP) dalam rangka memecah suara Partai Golkar di sana.

Alasan kelima yang mendorong dilakukannya pemekaran adalah adanya keinginan mengambil keuntungan (rent seeking) dari insentif fiskal yang diberikan pemerintah pusat dan daerah induk. Sama seperti alasan sebelumnya, alasan insentif fiskal ini juga tidak pernah secara eksplisit disampaikan. Insentif fiskal tersebut antara lain adanya anggaran tersendiri dari pemerintah pusat yang terpisah dari pemerintah daerah induk. Sebagaimana diketahui daerah yang dimekarkan akan mendapatkan anggaran dari daerah induk selama 3 tahun dan mendapatkan dana dari pemerintah pusat (DAU dan DAK). Fitrani, Hofman dan Kai (2005) menyatakan bahwa pemekaran telah membuka peluang terjadinya bureaucratic and political rent-seeking, yakni kesempatan untuk memperoleh keuntungan dana, baik dari pemerintah pusat maupun dari penerimaan daerah sendiri.

\section{Belanja Pemerintah}

Belanja pemerintah merupakan instrumen untuk mengukur besarnya peran pemerintah maupun peran pihak swasta. Selain itu pengeluaran pemerintah dapat digunakan sebagai penentu jumlah pengeluaran aggregat maupun penentu 
pertumbuhan PDB riil dalam jangka pendek. Pengeluaran pemerintah atas barang maupun jasa dikelompokkan ke dalam dua kelompok yaitu konsumsi pemerintah dan investasi pemerintah. Yang termasuk dalam golongan yang pertama (konsumsi pemerintah) adalah pembelian ke atas barang dan jasa yang akan dikonsumsikan, seperti membayar gaji guru sekolah, membeli alat-alat tulis dan kertas untuk digunakan dan membeli bensin untuk kendaraan pemerintah. Sedangkan investasi pemerintah meliputi pengeluaran untuk membangun prasarana seperti jalan, sekolah, rumah sakit dan irigasi (Soekirno, 2006).

Secara empirik, belanja pemerintah dianggap sebagai implementasi dari peran atau campur tangan pemerintah dalam meningkatkan kesejahteraan ekonomi masyarakat. Ada beberapa teori yang menunjukkan bahwa perkembangan peran pemerintah dalam pembangunan kesejahteraan ekonomi tidak pernah bisa dihilangkan. Bahkan, teori-teori tersebut justru mengemukakan bahwa peran pemerintah malah akan semakin meningkat seiring dengan berkembangnya kondisi perekonomian. Teori-teori tersebut antara lain:

\section{a. Model Rostow dan Musgrave}

Model Rostow dan Musgrave berisi tentang perkembangan pengeluaran pemerintah. Model ini menghubungkan perkembangan pengeluaran pemerintah dengan tahaptahap pembangunan ekonomi yaitu tahap awal, tahap menengah dan tahap lanjut. Pada tahap awal perkembangan ekonomi, persentase investasi pemerintah terhadap total investasi besar sebab pada tahap ini pemerintah harus menyediakan prasarana seperti pendidikan, kesehatan, prasarana transportasi. Pada tahap menengah pembangunan ekonomi, investasi pemerintah tetap diperlukan untuk meningkatkan pertumbuhan ekonomi agar dapat tinggal landas, namun pada tahap ini peranan investasi swasta sudah semakin besar. Peranan pemerintah tetap besar pada tahap menengah, oleh karena peranan swasta semakin besar akan menimbulkan banyak kegagalan pasar dan juga menyebabkan pemerintah harus menyediakan barang dan jasa publik dalam jumlah yang lebih banyak. Musgrave berpendapat bahwa dalam suatu proses pembangunan, investasi swasta dalam persentase terhadap PDB semakin besar dan persentase investasi pemerintah terhadap PDB akan semakin kecil. Pada tingkat ekonomi lebih lanjut, Rostow mengatakan bahwa aktivitas pemerintah dalam pembangunan ekonomi beralih dari penyediaan prasarana ke pengeluaran-pengeluaran untuk aktivitas sosial seperti program kesejahteraan hari tua dan pelayanan kesehatan masyarakat. (Mangkoesoebroto, 2008)

\section{b. Hukum Wagner}

Hukum Wagner dikenal dengan "The Law of Expanding State Expenditure". Dasar dari hukum tersebut adalah pengamatan empiris dari negaranegara maju (Amerika Serikat, Jerman, Jepang). Dalam hal ini Adolf Wagner menerangkan mengapa peranan pemerintah menjadi semakin besar, terutama disebabkan karena pemerintah harus mengatur hubungan yang timbul dalam masyarakat. Menurut Wagner, ketika ekonomi menjadi industri, hubungan antar pasar dan agen dalam pasar menjadi semakin kompleks. Situasi ini memerlukan peraturan perdagangan dan sistem hukum untuk mengaturnya. Eksternalitas akibat urbanisasi juga membutuhkan intervensi dan peraturan sektor publik. Dari pengamatan itu Wagner kemudian mengemukakan suatu teori mengenai perkembangan pengeluaran pemerintah yang semakin besar dalam prosentase terhadap PDB. Wagner menyatakan bahwa dalam suatu 
perekonomian apabila pendapatan per kapita meningkat maka secara relatif pengeluaran pemerintah pun akan meningkat. (Mangkoesoebroto, 2008)

\section{Tenaga Kerja}

Badan Pusat Statistik (BPS) mendefinisikan tenaga kerja sebagai seluruh penduduk dalam usia kerja (berusia 15 tahun atau lebih) yang potensial dapat memproduksikan barang dan jasa. Sebelum tahun 2000, Indonesia menggunakan dasar kriteria seluruh penduduk berusia 10 tahun ke atas. Selanjutnya mulai Sensus Penduduk 2000 dan sesuai dengan ketentuan secara internasional, tenaga kerja adalah penduduk yang berusia 15 tahun atau lebih. Kriteria ini menjadi indikator yang digunakan dalam pembuat kebijakan perencanaan ketenagakerjaan, baik di daerah maupun nasional. Indikator ini juga digunakan untuk mengetahui berapa banyak tenaga kerja atau penduduk usia kerja potensial yang dapat memproduksikan barang dan jasa.

Dalam statistik ketenagakerjaan di Indonesia, selain istilah angkatan kerja juga terdapat istilah kesempatan kerja. BPS mendefinisikan kesempatan kerja sebagai jumlah penduduk yang berusia 15 tahun ke atas yang bekerja menurut lapangan pekerjaan utama. Kesempatan kerja merupakan terjemahan bagi employment yang berarti sebagai jumlah orang yang bekerja tanpa memperhitungkan berapa banyak pekerjaan yang dimiliki tiap orang, pendapatan dan jam kerja mereka. Kesempatan kerja juga dapat dimaknai sebagai permintaan tenaga kerja (demand for labor), yaitu suatu keadaan yang menggambarkan tersedianya lapangan kerja yang siap diisi para pencari kerja.

Besarnya kesempatan kerja tergantung pada beberapa faktor, di antaranya: pertumbuhan output, tingkat upah dan harga-harga dari faktor produksi lainnya. Dikemukakan Tambunan (2001) bahwa hubungan antara pertumbuhan output dengan peningkatan jumlah kesempatan kerja dapat digambarkan lewat hubungan antara pasar barang dengan pasar tenaga kerja, di mana melalui mekanisme pasar terjadi pertemuan antara permintaan dan penawaran. Di pasar tenaga kerja, rumah tangga menawarkan jasanya dan mendapatkan harga (gaji). Apabila permintaan konsumsi rumah tangga di pasar barang meningkat, maka produksi dari sisi penawaran pasar barang meningkat dan terjadilah pertumbuhan output. Apabila di semua pasar terjadi peningkatan output, maka secara agregat terjadi pertumbuhan ekonomi. Pertumbuhan ekonomi akan mendorong adanya pertumbuhan kesempatan kerja. Semakin tinggi pertumbuhan ekonomi, maka akan semakin tinggi pula pertumbuhan kesempatan kerja.

\section{Pertumbuhan Ekonomi}

Kemajuan ekonomi suatu daerah menunjukkan keberhasilan suatu pembangunan meskipun bukan merupakan satu-satunya indikator keberhasilan pembangunan (Todaro, Smith, 2006). Ada tiga macam ukuran untuk menilai pertumbuhan ekonomi yaitu pertumbuhan output, pertumbuhan output per pekerja, dan pertumbuhan output per kapita. Pertumbuhan output digunakan untuk menilai pertumbuhan kapasitas produksi yang dipengaruhi oleh adanya peningkatan tenaga kerja dan modal di wilayah tersebut. Pertumbuhan output per tenaga kerja sering digunakan sebagai indikator adanya perubahan daya saing wilayah tersebut (melalui pertumbuhan produktivitas). Sedangkan pertumbuhan output per kapita digunakan sebagai indikator perubahan kesejahteraan ekonomi.

Model Solow sebagai salah satu model pertumbuhan ekonomi memberikan analisis statis bagaimana keterkaitan antara akumulasi modal, pertumbuhan populasi penduduk, dan perkembangan teknologi serta pengaruh ketiganya terhadap tingkat produksi output. Teori yang dicetuskan oleh Robert Solow ini memberikan jawaban atas pertanyaan mengapa perekonomian di suatu negara bisa tumbuh 
lebih cepat daripada pertumbuhan ekonomi di negara lain.

Model pertumbuhan Solow menggunakan dua buah faktor produksi utama, yakni: modal dan tenaga kerja, serta sebuah unsur baru yakni teknologi. Modal dan tenaga kerja dapat saling mensubtitusi satu sama lain. Solow mengasumsikan bahwa setiap faktor produksi akan mengalami diminishing return, yakni jika input ditambahkan terus menerus maka output akan bertambah tetapi dengan tingkat pertambahan yang semakin mengecil. Oleh karena itu investasi yang terus-menerus belum tentu akan dapat memberikan pertumbuhan yang permanen. Dengan demikian kemajuan teknologi akan sangat menentukan pertumbuhan ekonomi dalam jangka panjang. Bentuk model Solow didasarkan pada fungsi produksi sederhana dari Output (Y), Kapital (K) dan tenaga kerja (L) serta teknologi (T) sebagaimana tampak pada persamaan berikut:

$$
\mathrm{Y}=\mathrm{f}(\mathrm{K}, \mathrm{L}, \mathrm{T})
$$

Dalam pandangan Solow, teknologi merupakan faktor eksogen. Dampak dari kemajuan teknologi adalah dapat memunculkan pertumbuhan ekonomi secara berkelanjutan karena teknologi dapat mengoptimalkan efisiensi tenaga kerja yang terus tumbuh.

Menurut teori Solow ada beberapa hal yang dilakukan untuk memacu pertumbuhan ekonomi. Pertama, meningkatkan porsi tabungan akan meningkatkan akumulasi modal dan mempercepat pertumbuhan ekonomi. Kedua, meningkatkan investasi yang sesuai dalam perekonomian baik dalam bentuk fisik maupun non-fisik. Ketiga, mendorong kemajuan teknologi dapat meningkatkan pendapatan per tenaga kerja sehingga pemberian kesempatan untuk berinovasi pada sektor swasta akan berpengaruh besar dalam pertumbuhan ekonomi.

\section{METODE PENELITIAN}

Penelitian ini melibatkan variabel: pertumbuhan ekonomi, belanja pemerintah, infrastruktur, dan tenaga kerja. Definisi operasional dari masing-masing variabel adalah sebagai berikut:

a. Pertumbuhan ekonomi menggunakan indikator angka PDRB Tanpa Minyak dan Gas dari kabupaten/kota hasil pemekaran atas dasar harga konstan tahun 2000 dalam milyar rupiah.

b. Belanja pemerintah yaitu realisasi belanja pemerintah kabupaten/kota hasil pemekaran dalam milyar rupiah.

c. Tenaga Kerja adalah jumlah kesempatan kerja (employment), yakni: penduduk usia 15 tahun ke atas yang sedang bekerja menurut lapangan pekerjaan utama yang ada di kabupaten/kota hasil pemekaran dalam orang.

Populasi penelitian ini adalah pemerintah kabupaten/kota hasil pemekaran daerah di seluruh Indonesia yang penetapannya setelah diberlakukannya UU No. 22 tahun 1999 tentang otonomi daerah dan telah berusia lebih dari 5 tahun (per 31 Desember 2010). Dalam kajian ini dipilih 45 sampel secara random yang berasal dari 135 kabupaten/kota hasil pemekaran daerah yang penetapannya dilakukan antara tahun 1999 hingga 2005. Daerah pemekaran di Pulau Jawa tidak dapat dijadikan sampel karena pola pembentukan daerah otonom barunya relatif mirip, yakni dari Kabupaten menjadi Kota. Daerah konflik atau daerah yang menghadapi bencana alam juga tidak dimasukkan ke dalam sampel.

Data yang dipergunakan dalam penelitian ini adalah data sekunder. Data sekunder adalah data yang diperoleh lewat pihak lain, tidak langsung diperoleh dari peneliti dari subyek penelitiannya. Data sekunder biasanya berwujud data dokumentasi atau data laporan yang telah tersedia. Data sekunder yang dipakai adalah Laporan Keuangan Pemerintah Daerah (LKPD) dari 45 pemerintah kabupaten/kota hasil pemekaran yang dijadikan sampel dalam penelitian ini. Data LKPD yang diperoleh dari Badan 
Pemeriksa Keuangan (BPK) ini diperlukan untuk mengetahui besar realisasi belanja pemerintah dari kabupaten/kota yang dijadikan sampel. Data yang dianalisis berasal dari LKPD tahun anggaran 20082010.

Selain itu, data sekunder yang lain adalah data dari Badan Pusat Statistik (BPS), khususnya yang berkaitan dengan data pertumbuhan ekonomi (PDRB) dan infrastruktur. Untuk data jumlah tenaga kerja diambil dari Pusat Data dan Informasi Ketenagakerjaan, Kementerian Tenaga Kerja dan Transmigrasi.

Tujuan penelitian ini adalah ingin menganalisis pengaruh variabel independen terhadap variabel dependennya. Di sisi lain, penelitian ini melibatkan data yang bersifat time series (runtut waktu) dan cross section (lintas bagian). Sifat time series terlihat dari diambilnya kurun waktu 3 tahun, sedangkan cross section terlihat dari dijadikannya 45 kabupaten/kota sebagai sampel. Mempertimbangkan hal itu, analisis data yang digunakan dalam penelitian ini adalah metode regresi data panel. Data panel adalah gabungan antara data time series dengan data cross section.

Tabel 1. Kabupaten/Kota Hasil Pemekaran yang Dijadikan Sampel Berdasarkan Provinsi

\begin{tabular}{rllc}
\hline \hline No & \multicolumn{1}{c}{ Provinsi } & \multicolumn{1}{c}{ Kabupaten/Kota } & Jml \\
\hline 1. & Aceh & Kab. Gayo Lues & 1 \\
2. & Sumatera Utara & Kab. Serdang Bedagai, Kota Padang Sidimpuan & 2 \\
3. & Sumatera Barat & Kab. Dharmasraya, Kab. Pasaman Barat & 2 \\
4. & Riau & Kab. Rokan Hilir, Kab. Kuantan Singingi & 2 \\
5. & Jambi & Kab. Tebo, Kab. Muaro Jambi & 2 \\
6. Sumatera Selatan & Kab. OKU Selatan & 1 \\
7. & Bengkulu & Kab. Kepahiang, Kab. Lebong & 2 \\
8. & Lampung & Kab. Lampung Timur, Kota Metro & 2 \\
9. & Bangka Belitung & Kab. Bangka Barat, Kab. Belitung Timur & 2 \\
10. & Kepulauan Riau & Kab. Lingga, Kota Tanjung Pinang & 2 \\
11. & Nusa Tenggara Barat & Kab. Sumbawa Barat & 1 \\
12. & Nusa Tenggara Timur & Kab. Lembata, Kab. Manggarai Barat & 2 \\
13. & Kalimantan Barat & Kab. Bengkayang, Kab. Sekadau & 2 \\
14. Kalimantan Tengah & Kab. Lamandau, Kab. Barito Timur & 2 \\
15. & Kalimantan Selatan & Kota Banjarbaru, Kab. Tanah Bumbu & 2 \\
16. & Kalimantan Timur & Kab. Kutai Timur & 1 \\
17. & Sulawesi Utara & Kab. Kepulauan Talaud, Kab. Minahasa Selatan & 2 \\
18. & Sulawesi Tengah & Kab. Morowali, Kab. Banggai Kepulauan & 2 \\
19. Sulawesi Selatan & Kab. Luwu Utara, Kab. Luwu Timur & 2 \\
20. & Sulawesi Tenggara & Kab. Bombana, Kab. Wakatobi & 2 \\
21. & Gorontalo & Kab. Boalemo & 1 \\
22. & Sulawesi Barat & Kab. Mamuju Utara & 1 \\
23. & Maluku & Kab. Kepulauan Aru, Kab. Seram Bagian Barat & 2 \\
24. Maluku Utara & Kab. Kepulauan Sula & 1 \\
25. & Papua & Kab. Keerom, Kab. Supiori & 2 \\
26. & Papua Barat & Kab. Raja Ampat, Kab. Teluk Wondama & T5 \\
\hline & & & \\
\hline \hline
\end{tabular}


Sesuai dengan masalah penelitian tersebut serta mengacu pada model Solow dalam menganalisis pertumbuhan ekonomi, maka dalam penelitian ini model persamaan regresi yang digunakan adalah sebagai berikut:

$$
\ln \mathrm{Y}_{\mathrm{it}}=\beta_{0 \mathrm{it}}+\ln \beta_{1} \mathrm{G}_{\mathrm{it}}+\ln \beta_{2} \mathrm{I}_{\mathrm{it}}+\ln \beta_{3} \mathrm{~L}_{\mathrm{it}}+\mu_{\mathrm{it}}
$$

dimana:

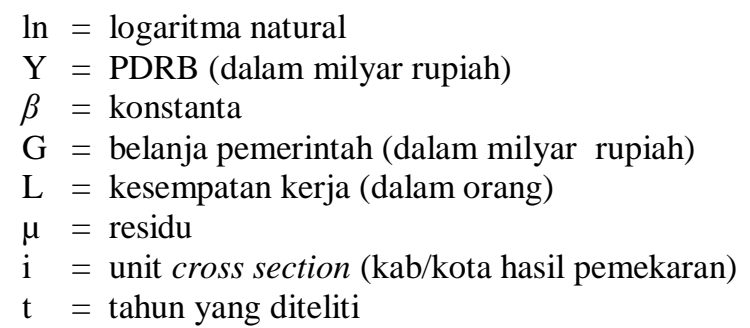

\section{HASIL DAN PEMBAHASAN}

\section{Perkembangan PDRB}

Nilai PDRB Tanpa Minyak dan Gas Berdasarkan Harga Konstan Tahun 2000 di kabupaten/kota hasil pemekaran selama periode 2008-2010 menunjukkan komposisi yang sangat beragam Dari 45 kabupaten/kota hasil pemekaran yang dijadikan sampel, terlihat bahwa PDRB Kabupaten Kutai Timur memiliki nilai rata-rata tertinggi, yakni: 15.545 milyar rupiah. Nilai rata-rata PDRB Kabupaten Kutai Timur ini bahkan sangat jauh dibandingkan dengan rata-rata PDRB Kabupaten Sumbawa Barat yang berada di posisi kedua dengan nilai rata-rata mencapai 4.737 milyar rupiah. Jika dicermati lebih jauh, hanya ada 17 kabupaten/kota hasil pemekaran $(37,8$ persen) yang memiliki rata-rata PDRB di atas 1 triliun rupiah. Sisanya, yakni 28 kabupaten/kota hasil pemekaran (62,2 persen) memiliki nilai rata-rata PDRB di bawah 1 triliun rupiah. Bahkan, 4 kabupaten/ kota di antaranya hanya memiliki rata-rata PDRB di bawah 200 miliar rupiah, yakni: Kabupaten Supiori (118 miliar rupiah), Kabupaten Lembata (146 miliar rupiah), Kabupaten Teluk Wondama (177 miliar rupiah), dan
Kabupaten Kepulauan Aru (198 miliar rupiah). Situasi ini menggambarkan betapa jauhnya kesenjangan kinerja perekonomian di antara kabupaten/kota hasil pemekaran.

Ada catatan menarik terkait perbedaan tingkat perekonomian kabupaten/kota hasil pemekaran yang cukup jauh. Pertama, dari perhitungan statistik diketahui bahwa tidak terdapat korelasi yang cukup kuat antara usia kabupaten/kota hasil pemekaran dengan rata-rata PDRB masing-masing, ditunjukkan dari nilai $r$ yang hanya 0,2117 . Kedua, sektor pertanian masih menjadi sektor utama (leading sector) bagi sebagian besar kabupaten/kota hasil pemekaran dalam memacu pertumbuhan ekonominya. Dari 45 kabupaten/kota hasil pemekaran yang diteliti, 35 kabupaten mengandalkan sektor pertanian, kehutanan, dan perikanan sebagai sektor terbesar (leading sector). Ketiga, meskipun terdapat 35 kabupaten yang mengandalkan sektor pertanian, kehutanan, dan perikanan sebagai sektor terbesar (leading sector), namun hanya 10 kabupaten/kota hasil pemekaran yang berhasil mencapai ratarata PDRB di atas 1 trilyun rupiah.

Secara keseluruhan selama periode 2008-2010 laju perkembangan PDRB Tanpa Minyak dan Gas di kabupaten/kota hasil pemekaran menunjukkan peningkatan yang positif. Bahkan jika dibandingkan dengan laju PDB nasional Tanpa Minyak dan Gas pada periode yang sama terdapat fenomena yang menarik. Di tahun 2009, saat laju PDB nasional mengalami penurunan, laju PDRB kabupaten/kota hasil pemekaran justru mengalami peningkatan besar. 


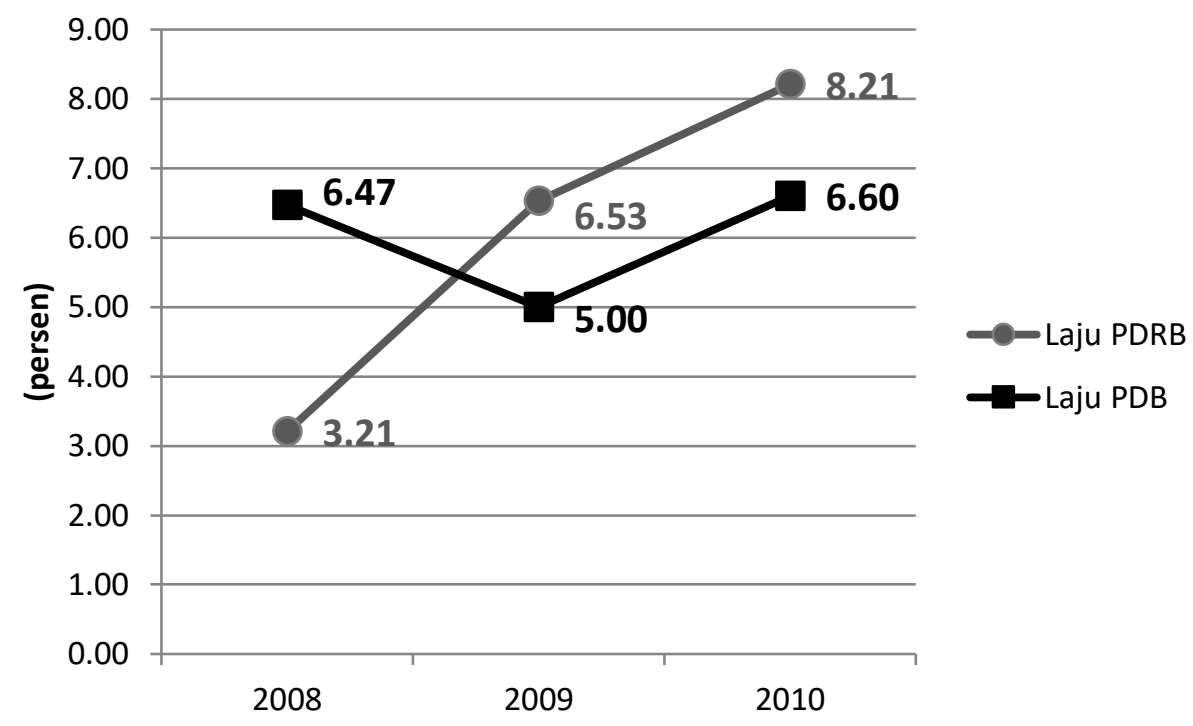

Sumber: diolah dari data BPS 2012

Gambar 1. Perbandingan Laju PDRB 45 Kabupaten/Kota Hasil Pemekaran dengan Laju PDB Nasional 2008-2010 (dalam persen).

Ada beberapa kemungkinan mengapa di saat PDB nasional mengalami penurunan, namun PDRB kabupaten/kota hasil pemekaran tetap mengalami peningkatan. Argumentasi pertama adalah sebagian besar kabupaten /kota hasil pemekaran mengandalkan sektor pertanian, kehutanan, dan perikanan sebagai sektor utama dalam mendorong pertumbuhan ekonomi mereka-sebagaimana telah dipaparkan sebelumnya. Sektor ini relatif kebal dampak terhadap situasi keuangan global yang saat itu tengah mengalami krisis. Karena sektor ini lebih berorientasi pada pemenuhan kebutuhan domestik dan tidak terkait dengan pergerakan di pasar modal, menjadikan gejolak ekonomi di luar negeri tidak mempengaruhi pertumbuhan sektor ini.

Argumentasi kedua adalah semua kabupaten/kota hasil pemekaran yang dijadikan sampel pada penelitian ini berasal dari luar Jawa. Sementara, motor perekonomian nasional masih lebih banyak ditopang di Jawa. Hal ini bisa dicermati dari kontribusi PDRB 45 kabupaten/kota hasil pemekaran terhadap PDB yang hanya berkisar 3,7 persen. Artinya, peningkatan PDRB kabupaten/kota hasil pemekaran tidak banyak pengaruhnya terhadap pertumbuhan PDB nasional.

Argumentasi ketiga adalah kuatnya pengaruh konsumsi rumah tangga terhadap PDB yang antara lain didorong peningkatan belanja pemerintah. Pada tahun 2009, pertumbuhan belanja pemerintah cukup tinggi, yakni mencapai 19,25 persen. Peningkatan belanja pemerintah tersebut teraktualisasi melalui pengeluaran terkait penyelenggaraan Pemilu 2009, program sosial, dan kenaikan gaji PNS. Berdasarkan kajian yang dilakukan UNDP dan Bappenas tahun 2008 diketahui bahwa jumlah penduduk miskin di kabupaten/kota hasil pemekaran relatif masih tinggi. Oleh karena itu, keberadaan program sosial dan pengeluaran terkait Pemilu 2009 cukup membantu peningkatan konsumsi rumah tangga miskin di kabupaten/kota hasil pemekaran sehingga turut mendorong pertumbuhan PDRB.

\section{Perkembangan Belanja Pemerintah}

Dalam pandangan ekonom neoklasik, salah satu faktor yang mempengaruhi pertumbuhan ekonomi adalah pembentukan kapital/modal. Dengan pemahaman tersebut, besarnya belanja pemerintah daerah dinilai akan 
mempengaruhi pertumbuhan ekonomi daerah bersangkutan. Secara kumulatif, nilai agregat realisasi total belanja pemerintah kabupaten/kota hasil pemekaran menunjukkan peningkatan dari tahun ke tahun dalam periode tahun anggaran 2008-2010 (Gambar 2). Demikian halnya dengan laju PDRB kabupaten/kota hasil pemekaran selama 2008-2010, terjadi peningkatan setiap tahun (Gambar 1). Kondisi ini sesuai dengan hukum Wagner yang menyatakan bahwa semakin tinggi PDB/PDRB akan semakin tinggi pula pengeluaran (belanja) pemerintah.

Dari hasil analisis terhadap laporan realisasi APBD kabupaten/kota hasil pemekaran untuk tahun anggaran 2008-
2010, ditemukan bahwa realisasi total belanja 45 pemerintah daerah kabupaten/kota hasil pemekaran selalu menunjukkan adanya peningkatan tiap tahunnya. Namun jika dicermati lebih jauh, peningkatan realisasi total belanja tersebut tidak selalu diikuti dengan peningkatan realisasi belanja modal (Gambar 2). Realisasi anggaran tahun 2009 menunjukkan bahwa meskipun total belanja pemerintah meningkat dibanding realisasi anggaran tahun sebelumnya, tapi pada realisasi belanja modal justru mengalami penurunan dibanding tahun 2008. Demikian pula yang terjadi di tahun anggaran 2010.

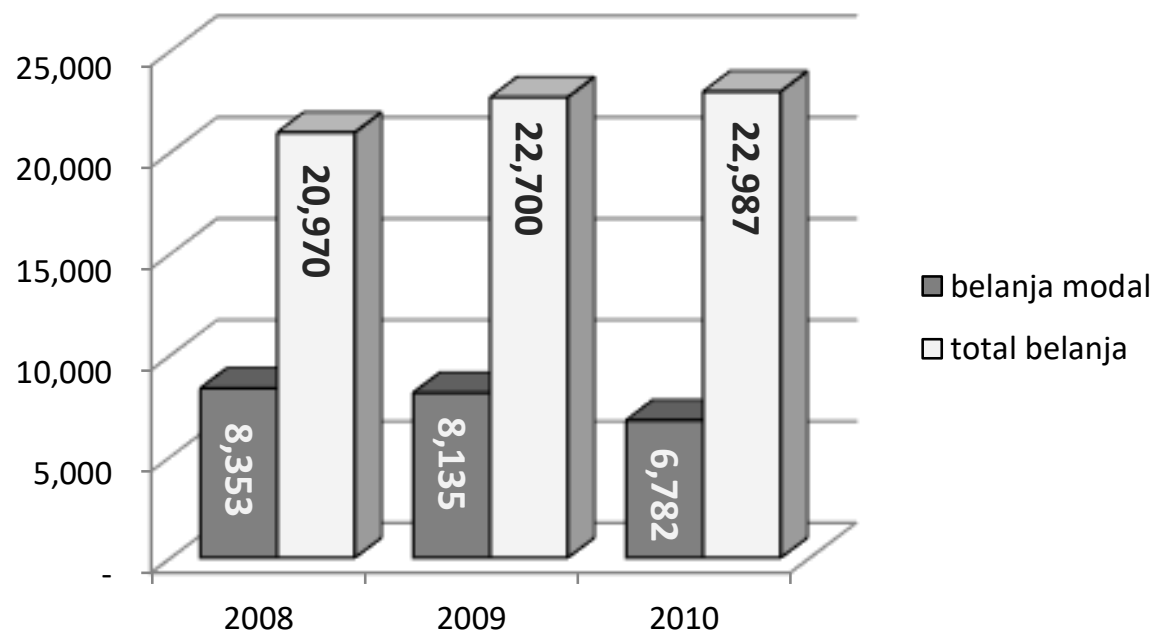

Sumber: diolah dari data BPK 2008-2010

Gambar 2. Perkembangan Realisasi Belanja Modal dan Total Belanja Pemerintah 45

Kabupaten/Kota Hasil Pemekaran Tahun Anggaran 2008-2010 (dalam miliar rupiah)

Kondisi tersebut menunjukkan bahwa terdapat alokasi belanja di luar Belanja Modal yang mengalami peningkatan besar. Dari hasil pengamatan terhadap LKPD kabupaten/kota hasil pemekaran di tahun anggaran 2009 terlihat bahwa rata-rata di tahun anggaran tersebut terdapat peningkatan cukup besar pada alokasi Belanja Operasi sub Belanja Sosial. Hal ini bisa dimengerti karena pada tahun 2009 merupakan tahun pemilu dimana para elit politik daerah kabupaten/kota hasil pemekaran mengalokasikan Belanja Sosial yang sangat besar untuk kepentingan politik partai yang mengusung mereka.

Kesimpulan tersebut semakin menemukan pembenarannya manakala melihat penurunan realisasi Belanja Sosial di tahun 2010. Meskipun terjadi penurunan pada realisasi Belanja Modal dan sub Belanja Sosial, namun realisasi Total Belanja Pemerintah pada pada tahun 2010 tetap mengalami peningkatan dibanding tahun 2009, meski tidak begitu tinggi. Peningkatan tersebut sebagian besar ditopang oleh peningkatan pada alokasi 
Belanja Operasi sub Belanja Pegawai. Hal ini terkait dengan banyaknya penambahan aparat baru di pemerintah daerah kabupaten/kota hasil pemekaran tahun 2010.

\section{Perkembangan Tenaga Kerja}

Konsekuensi dari adanya pemekaran daerah adalah berkurangnya jumlah penduduk secara drastis jika dibandingkan ketika masih bersama daerah induk. Akibatnya hal ini akan berdampak langsung terhadap jumlah tenaga kerja yang ada di daerah induk maupun daerah pemekaran. Dalam pandangan ekonomi neoklasik, penurunan jumlah tenaga kerja dinilai akan ikut menurunkan kemampuan dalam meningkatkan pertumbuhan ekonomi.

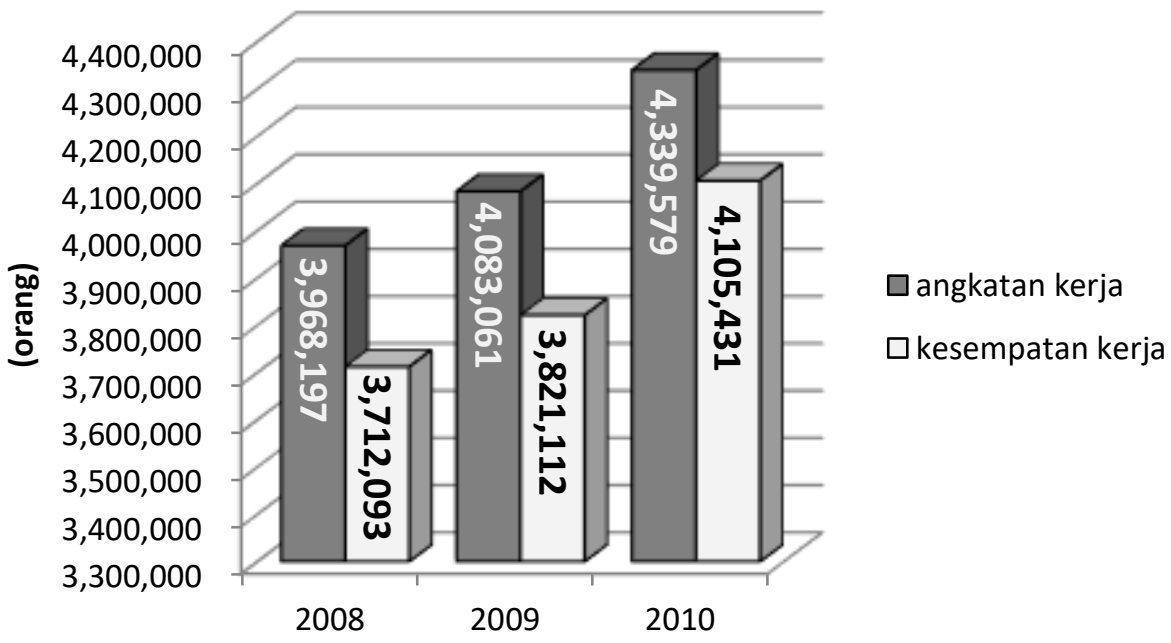

Sumber: diolah dari data BPS 2012

Gambar 3. Perkembangan Jumlah Angkatan Kerja dan Kesempatan Kerja 45 Kabupaten /Kota Hasil Pemekaran 2008-2010 (dalam orang)

Secara keseluruhan, selama periode 20082010 terjadi peningkatan jumlah tenaga kerja, baik dalam pengertian angkatan kerja maupun kesempatan kerja, di kabupaten/kota hasil pemekaran (Gambar 4). Peningkatan jumlah angkatan kerja yang diiringi dengan peningkatan jumlah kesempatan kerja di kabupaten/kota hasil pemekaran mengindikasikan bahwa kinerja perekonomian telah menghasilkan pasar tenaga kerja yang positif. Artinya, pertambahan supply tenaga kerja masih bisa diimbangi dengan pertambahan demand tenaga kerja. Hanya saja, pertambahan demand tenaga kerja (kesempatan kerja) masih belum cukup optimal dalam menekan pertambahan supply tenaga kerja. Akibatnya, jumlah angkatan kerja masih jauh lebih tinggi dibanding jumlah kesempatan kerja.

\section{Pengaruh Belanja Pemerintah dan Tenaga Kerja terhadap PDRB}

Berdasarkan hasil Likehood Ratio Test dan Hausman Test dapat diketahui bahwa Model Fixed Effects adalah model yang lebih baik daripada Model Common Effects maupun Model Random Effects. Kemudian untuk menilai apakah persamaan yang dihasilkan memenuhi asumsi BLUE (Best Linear Unbiased Estimator), dilakukan berbagai uji asumsi klasik. Hasil uji asumsi klasik yang meliputi: uji normalitas, uji multikolineritas, uji autokorelasi, dan uji heteroskedasitas, memperlihatkan bahwa persamaan regresi yang digunakan dalam analisis ini memenuhi semua uji klasik tersebut sehingga dapat dikatakan bahwa 
persamaan yang digunakan telah memenuhi asumsi BLUE.

Hasil perhitungan mengenai pengaruh belanja pemerintah dan tenaga kerja terhadap pertumbuhan ekonomi kabupaten/kota hasil pemekaran dengan menggunakan Eviews 6.0 (Tabel 2).

Tabel 2. Model Persamaan Regresi Data Panel

\begin{tabular}{ccccr}
\hline \hline Variable & Coefficient & Std. Error & t-Statistic & Prob. \\
\hline const & 2,061503 & 0,809716 & 2,545957 & 0,0126 \\
$\mathrm{G}$ & 0,223534 & 0,067186 & 3,327068 & 0,0013 \\
$\mathrm{~L}$ & 0,298281 & 0,074189 & 4,020531 & 0,0001 \\
\hline R-squared & 0,997799 & Mean dependent var & 6,734427 \\
Adjusted $R$-squared & 0,996649 & S.D. dependent var & 1,070474 \\
$F$-statistic & 867,4359 & Durbin-Watson stat & 1,788906 \\
Prob $(F$-statistic $)$ & 0,000000 & & \\
\hline \hline
\end{tabular}

Sumber: data olahan

Dari persamaan model di atas, dapat diinterpretasikan bahwa variabel Belanja Pemerintah (G) memiliki pengaruh yang positif terhadap PDRB Kabupaten/Kota Hasil Pemekaran dengan koefisien sebesar 0,223534 . Hal ini berarti bahwa setiap kenaikan Belanja Pemerintah sebesar 1 persen akan meningkatkan PDRB sebesar 0,223534 persen (dengan asumsi ceteris paribus). Memperhatikan $p$-value dari $t$ Statistics sebesar 0,0013 menunjukkan bahwa variabel Belanja Pemerintah berpengaruh signifikan terhadap PDRB. Hasil tersebut sesuai dengan Teori Solow yang menyebutkan bahwa salah satu sumber pertumbuhan ekonomi berasal dari akumulasi modal. Semakin besar akumulasi modal maka akan semakin besar pula pertumbuhan ekonomi suatu daerah. Hasil ini juga sesuai dengan penelitian Mubaroq, et al. (2013) dan Candra (2012). Kedua penelitian tersebut menemukan bahwa investasi (belanja) pemerintah memiliki pengaruh positif yang signifikan terhadap pertumbuhan ekonomi.

Kondisi yang sama juga terjadi pada variabel Tenaga Kerja (L) yang menggunakan indikator angka kesempatan kerja. Variabel ini memiliki pengaruh yang positif terhadap PDRB Kabupaten/Kota Hasil Pemekaran dengan koefisien sebesar 0,298281 . Nilai koefisien variabel tenaga kerja ini merupakan nilai yang lebih besar dibanding koefisien yang dihasilkan oleh variabel Belanja Pemerintah. Dengan nilai koefisien tersebut dapat diartikan bahwa setiap kenaikan jumlah kesempatan kerja sebesar 1 persen akan meningkatkan PDRB sebesar 0,298281 persen (dengan asumsi ceteris paribus). Memperhatikan $p$ value dari t-Statistics sebesar 0,0001 menunjukkan bahwa variabel Tenaga Kerja berpengaruh sangat signifikan terhadap PDRB. Hasil ini sesuai dengan Teori Solow menjelaskan bahwa tenaga kerja merupakan salah satu faktor yang dapat mempengaruhi pertumbuhan ekonomi suatu daerah. Hasil ini juga senada dengan penelitian yang dilakukan Mubaroq et.al (2013) dan Candra (2012).

\section{SIMPULAN DAN SARAN}

\section{Simpulan}

Berdasarkan pembahasan dan analisis yang dilakukan dalam kajian ini, dapat ditarik simpulan sebagai berikut:

1. Rata-rata pertumbuhan ekonomi kabupaten/kota hasil pemekaran selama periode 2008-2010 yang diindikasikan dari angka rata-rata PDRB kabupaten/kota hasil pemekaran menunjukkan adanya peningkatan setiap tahun. Bahkan di saat laju PDB nasional mengalami penurunan di tahun 2009, laju rata-rata PDRB kabupaten/kota hasil pemekaran masih tetap positif. 
2. Nilai belanja pemerintah dan jumlah kesempatan kerja kabupaten/kota hasil pemekaran selama periode 2008-2010 menunjukkan adanya peningkatan setiap tahun.

3. Belanja pemerintah dan tenaga kerja memiliki pengaruh positif dan signifikan terhadap pertumbuhan ekonomi kabupaten/kota hasil pemekaran.

\section{Saran}

Memperhatikan simpulan di atas yang juga merupakan hasil dari kajian ini, maka saran yang dapat disampaikan adalah:

1. Pemerintah kabupaten/kota hasil pemekaran di Indonesia perlu memperbesar nilai belanja pemerintah yang secara empirik memiliki pengaruh yang siginifikan dalam meningkatkan pertumbuhan ekonomi. Sebagai daerah otonom baru, meniscayakan pemerintah kabupaten/kota hasil pemekaran untuk memberi porsi yang besar dalam pengeluaran/belanja untuk kepentingan investasi dan pembentukan kapital yang nantinya akan mendorong pertumbuhan ekonomi.

2. Pertumbuhan jumlah tenaga kerja perlu diimbangi dengan penumbuhan angka kesempatan kerja melalu peningkatan sektor-sektor perekonomian yang ada di tiap-tiap kabupaten/kota hasil pemekaran yang ada di Indonesia. Kajian ini menemukan bahwa sebagian besar kabupaen/kota hasil pemekaran masih mengandalkan sektor pertanian sebagai sektor utama dalam menyerap tenaga kerja. Oleh karena itu, pemerintah kabupaten/kota hasil pemekaran harus jeli menangkap potensi lokal yang mereka miliki untuk dapat menggerakkan semua sektorsektor perekonomian secara sinergis dan optimal agar dapat menyerap lebih banyak tenaga kerja.

3. Penelitian selanjutnya diharapkan dapat melihat kinerja perekonomian kabupaten/ kota hasil pemekaran dengan kerangka teori ataupun sisi pandang yang berbeda sehingga dapat melengkapi pemahaman yang telah didapatkan dalam kajian ini.

4. Kajian ini memiliki keterbatasan, terutama dari aspek rentang waktu pengambilan data yang digunakan untuk dianalisis. Oleh karena itu dalam penelitian berikutnya diharapkan dapat melakukan analisis pada rentang periode waktu yang lebih lebar sehingga dapat memberi pemahaman yang lebih luas.

5. Kajian ini menganalisis pertumbuhan ekonomi kabupaten/kota hasil pemekaran dengan mengambil sampel secara nasional. Melihat tingginya variasi data dari masing-masing kabupaten/kota hasil pemekaran secara nasional, terbuka kemungkinan pada penelitian berikutnya untuk mengambil skala atau cluster berdasarkan wilayah yang lebih homogen.

\section{DAFTAR PUSTAKA}

Badan Perencanaan Pembangunan Nasional (Bappenas), United Nations Development Programme (UNDP). 2008. Studi Evaluasi Dampak Pemekaran Daerah 2001 2007. Jakarta (ID): BRiDGE (Building and Reinventing Decentralised Governance) Bappenas.

Baltagi BH. 1995. Econometric Analysis of Panel Data, Chichester (UK): John Wiley \& Sons Ltd.

Boediono, 1995. Teori Pertumbuhan Ekonomi, Yogyakarta (ID): BPFE.

Candra EW. 2012. Analisis Peranan Pengeluaran Pemerintah, Tenaga Kerja dan Penanaman Modal Dalam Negeri (PMDN) terhadap Pertumbuhan Ekonomi Provinsi Jawa Timur Tahun 2001-2010, [internet][diunduh 2013 Apr 10]. Tersedia pada jimfeb.ub.ac.id/index.php/jimfeb/art icle/viewFile/147/113 
Direktorat Jenderal Otonomi Daerah, Kementrian Dalam Negeri, Decentralization Support Facility. 2011. Laporan Hasil Evaluasi Daerah Otonom Hasil Pemekaran (EDOHP) 2011. Jakarta (ID): Bank Dunia

Fitrani F, Hofman B, Kai K. 2005. Unity in Diversity? The Creation of New Local Government in A Decentralising Indonesia. Bulletin of Indonesian Economic Studies. 41(1): 57-79.

Gujarati DN. 2004. Basic Econometrics, 4th edition. New York (US): The McGraw-Hill Companies

Mailendra F. 2009. Analisis Dampak Pemekaran Wilayah dan Faktorfaktor yang Mempengaruhi Pembangunan Manusia di Propinsi Jawa Barat (Analisis Panel Data: Kabupaten/Kota di Jawa Barat Periode 2002-2006) [skripsi]. Bogor (ID): IPB

Mangkoesoebroto G. 2008. Ekonomi Publik (Edisi III). Yogyakarta (ID): BPFE

Mankiw G. 2000. Pengantar Ekonomi Jilid I. Jakarta (ID): Erlangga

Mubaroq MR, Remi SS, Muljarijadi B. 2013. Pengaruh Investasi Pemerintah, Tenaga Kerja, Desentralisasi Fiskal terhadap Pertumbuhan Ekonomi Kabupaten di Indonesia Tahun 2007-2010. [internet][diunduh 2013 Jan 25]. Tersedia pada http://pustaka.unpad.ac.id/ wpcontent/uploads/2013/01/Jurnal-MRizal-M-M-UNPAD.pdf

Pusat Kajian Kinerja Otonomi Daerah. 2005. "Laporan Evaluasi Penyelenggaran Otonomi Daerah Periode 1999-2003", Lembaga Administrasi Negara (LAN).

Ratnawati T, Jaweng RE. 2005. Meninjau Kebijakan Pemekaran Daerah. Jentera. 10 (3): 60

Sultani. 19 Nop 2012. Jajak Pendapat Kompas: Pemekaran Belum Bisa
Menyejahterakan. Kompas. Rubrik Politik \& Hukum: 5 (kol 1-7)

Suparmoko M. 2002. Ekonomi Sumber Daya Alam dan Lingkungan: Suatu Pendekatan Teoritis, Yogyakarta (ID): BPFE.

Tambunan TH. 2001. Industrialisasi di Negara Berkembang, Jakarta (ID): Ghalia Indonesia

Todaro MP, Smith SC. 2006. Ekonomi Pembangunan, Jakarta (ID): Erlangga

Wardman, M. 1998. The Value of Travel Time: A Review of British Evidence. Journal of Transport Economics and Policy 32(3): 285315.

World Bank. 1994. The World Bank Report: Infrastructure for Development, Washington DC (US): World Bank 